\title{
DESCRIPTIONS OF NEW TERRESTRIAL MOLLUSCA FROM NORTH-WEST CHINA.
}

By H. B. Preston, F.Z.S.

Read 10th November, 1911.

\section{Eulota (Cathaica) Orastias, n.sp.}

Shell rather small, perforate, depressedly turbinate, whitish above, painted with a supersutural band of reddish chestnut, which appears as a superperipheral band on the last whorl; base of shell ornamented with two or three zones of pale brown, which are transparent, and hetween which the ground-colour is of a rather yellowish white; whorls $5 \frac{1}{2}$, the apical whorls pale flesh-coloured and smooth, the remainder somewhat coarsely plicate and sculptured with very fine,

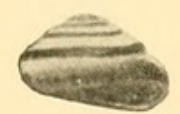

wavy, spiral striæ, which become more noticeable on the base of the shell; suture impressed; umbilicus rather narrow, deep; columella thin, outwardly expanded, descending in an abrupt curve; labrum simple, except at the base, where it is slightly internally thickened; aperture broadly and irregularly sub-lunate. Alt. $6.5 \mathrm{~mm}$; d diam. maj. $10 \cdot 25$, min. $9 \mathrm{~mm}$. Aperture: alt. $3 \cdot 25$, diam. $3.75 \mathrm{~mm}$.

Hab.-Mountains of S.E. Kan-su, at an altitude of from 2,000 to 5,000 feet.

\section{Eulota (Plectotropis) Wardi, n.sp.}

Shell very depressedly orbicular with slightly convex base, acutely carinated at the periphery, rather thin, light bronze colour, somewhat shining; whorls $5 \frac{3}{4}$, the last abruptly descending in front, sculptured with closely set, arcuate costulæ, hecoming much finer on the base, which is also sculptured with slightly distant, fine, revolving striæ; suture impressed, margined above with a narrow whitish callus which

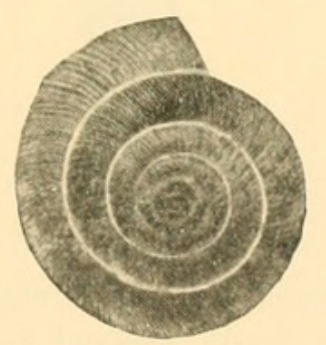

forms the carina on the last whorl; umbilicus very wide, open, moderately deep; labrum thickened, especially at the base, narrowly expanded, reflexed, continuous; aperture obliquely sub-quadrate, somewhat nasute in front. Alt. $5.5 \mathrm{~mm}$.; diam. maj. 18.5 , min. $16 \mathrm{~mm}$. Aperture : alt. $4 \cdot 5$, diam. $7 \mathrm{~mm}$.

Hab.-Limestone region, S.E. Kan-su, at an altitude of 3,000 feet.

A marvellously beautiful species, which I have much pleasure in dedicating to the discoverer. 


\section{Buliminus castaneo-balteatus, n.sp.}

Shell imperforate, subulately fusiform, with sub-mamillary apex; the apical whorls reddish chestnut, the later whorls bluish grey painted with irregular, oblique, transverse bands of the same colour; whorls 8 , not very convex, the last ascending in front, marked with very oblique irregular growth-lines; suture impressed, scarcely crenellate, very narrowly bunded with white below; umbilical area

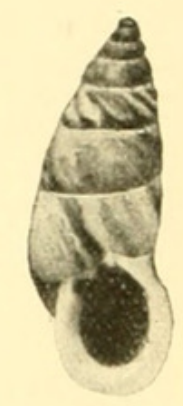

depressed; labrum white, broadly expanded, not reflexed, the margins joined by a callus which thickens almost into a tubercle just before its junction with the right margin, aperture ovate; interior of shell reddish chestnut. Alt. $21.5 \mathrm{~mm}$.; diam. maj. 12 , min. $8.75 \mathrm{~mm}$. Aperture: alt. $7 \cdot 5$, diam. $5 \mathrm{~mm}$.

Hab.-Limestone region, S.E. Kan-su, at an altitude of 3,000 feet.

\section{Buliminus ordinarius, n.sp.}

Shell perforate, fusiform, rather thin, somewhat polished, brown; whorls 7, moderately convex, the last two broad in proportion to the remainder, the last ascending in front, malleated and marked with very oblique, slightly arcuate growth-lines, and small interrupted spiral scratches; suture well impressed, very narrowly margined below; umbilicus rather broad above, rapidly narrowing to a mere

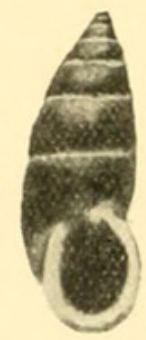

chink; labrum white, expanded, the margins converging and joined by a thin callus which thickens almost into a nodule where it reaches the right margin; aperture ovate; interior of shell pale brown. Alt. $17.5 \mathrm{~mm}$; diam. maj. $7 \cdot 25$, min. $5 \cdot 75 \mathrm{~mm}$. Aperture: alt. 5, diam. $3 \mathrm{~mm}$.

Hab.-Mountains of S.E. Kan-su, at an altitude of from 2,000 to 5,000 feet.

Bu i.minus oscitans, n.sp.

Shell thin, fusiform, scarcely perforate, slightly shining, dark livid flesh-colour, irregularly transversely banded with pale reddish chestnut, 
the last whorl painted with a very narrow, whitish spiral streak at the periphery ; whorls $6 \frac{1}{2}$, the apical whorls small, the last two very broad, the last ascending in front, rather flat, marked with lines of growth; suture impressed, narrowly margined below; columella descending obliquely; labrum white, thin, expanded, hardly reflexed,

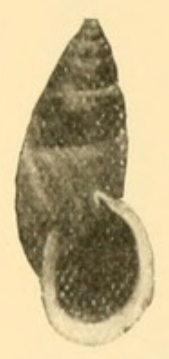

the margins joined $\mathrm{br}_{\mathrm{r}}$ an almost imperceptible callus; aperture vers large for the size of the shell, broadly inversely auriform; interior of shell reddish, polished, shining. Alt. $22 \cdot 75 \mathrm{~mm}$.; diam. maj. 10.5, min. $7.5 \mathrm{~mm}$. Aperture: alt. 9, diam. $5 \mathrm{~mm}$.

$H_{a b}$.-Limestone region, S.E. Kan-su, at an altitude of 3,000 feet.

Easily distinguished from other forms from this region by the exceptionally large aperture.

\section{Buliminus Wardi, n.sp.}

Shell fusiform, with rather acuminate apex, rimate, dark fleshcolour, obliquely transversely banded, and occasionally blotched with white; whorls 7, moderately convex, the later whorls rather rapidly increasing, marked with fine growth-striæ; suture well impressed,

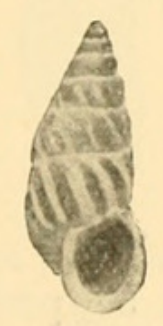

narrowly margined with white below; perforation reduced to a mere chink; labrum white, expanded, not reflexed, the margins joined by a light callus; aperture irregularly ovate. Alt. $15.5 \mathrm{~mm}$; diam. maj. 6.75 , min. $5.5 \mathrm{~mm}$. Aperture : alt. 4 , diam. $3 \mathrm{~mm}$.

Hab.-Mountains of S.E. Kan-su, at an altitude of from 2,000 to 5,000 feet.

\section{Buliminus (Serinds) sobrinds, n.sp.}

Shell cylindrically fusiform, pale flesh-colour, mottled and banded here and there with a darker shade of the same colour; whorls 11, somewhat convex, regularly and rather slowly increasing, malleated, occasionally almost sub-costulate, the last ascending in front, and somewhat dilated below, just behind the aperture; suture impressed, margined below; umbilical area forming a shallow, elongate 
depression; columella rather obliquely descending; labrum narrowly expanded, not reflexed, a very light, scarcely perceptible callus uniting the margins; aperture inversely auriform. Alt. $16.25 \mathrm{~mm}$., diam. maj. $3.75 \mathrm{~mm}$. Aperture : alt. 3 , diam. $2 \mathrm{~mm}$.

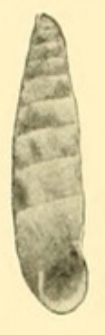

Hab.-Mountains of S.E. Kan-su, at an altitude of from 2,000 to 5,000 feet.

Closely allied to B. Szechenyi, Hilber, also from Kan-su, but with a broader and more ovate aperture, more convex whorls, and deeper suture.

\section{Buliminus (Napaus) Cookei, n.sp.}

Shell sinistral, rimate, fusiform, smooth but for growth-lines, scarcely shining, pale yellowish brown; whorls $7 \frac{1}{2}$, rather flat, the earlier whorls small, the last two rapidly increasing; sutures somewhat lightly impressed; umbilicus appearing as an extremely narrow

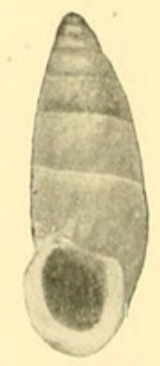

fissure; labrum white, expanded, the margins converging and united by such a thick callus as to be practically continuous; aperture rectangularly ovate. Alt. $18 \mathrm{~mm}$; diam. maj. 7, min. $6 \mathrm{~mm}$. Aperture: alt. 4 , diam. $3 \mathrm{~mm}$.

Hab.-Mountains of S.E. Kan-su, at an altitude of from 2,000 to 5,000 feet.

\section{Clausilia Cookei, n.sp. .}

Shell large, moderately solid, cylindrical, with verr obtuse apex, pale brownish straw-colour, somewhat shining; whorls 10, flat, the two last very broad, marked with fine, very closely set, oblique, transverse striæ ; suture impressed, slightly crenellate; labrum white, continuous, broadly expanded and reflexed below, exserted and narrowly reflexed above; aperture broadly, inversely auriform, armed with a high, erect, white lamella on the parietal wall suddenly decreasing in height, and curving round in the interior of the shell to form a junction with the columella plait, which is moderately broad 
and very oblique, and below which is situated a small, twisted, basal plication; a thin, elongate, revolving lamella is also visible on the outer wall, but situated well within the shell. Alt. $42 \mathrm{~mm}$.; diam. maj. 10, min. 8.75 mm. Aperture: alt. 8, diam. $5 \cdot 5 \mathrm{~mm}$.

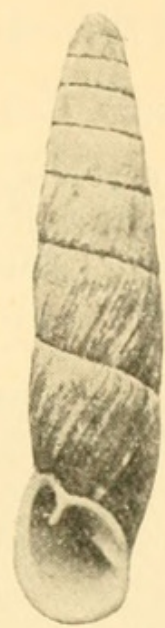

Hab.-From the Loess Plain of the Wei River, S. Shen-si, at an altitude of 1,200 feet. 


\section{$2 \mathrm{BHL}$ Biodiversity Heritage Library}

Preston, H B. 1912. "DESCRIPTIONS OF NEW TERRESTRIAL MOLLUSCA FROM NORTH-WEST CHINA." Proceedings of the Malacological Society of London 10, 11-15. https://doi.org/10.1093/oxfordjournals.mollus.a063453.

View This Item Online: https://www.biodiversitylibrary.org/item/52423

DOI: https://doi.org/10.1093/oxfordjournals.mollus.a063453

Permalink: https://www.biodiversitylibrary.org/partpdf/203070

\section{Holding Institution}

Smithsonian Libraries

\section{Sponsored by}

Smithsonian

\section{Copyright \& Reuse}

Copyright Status: Public domain. The BHL considers that this work is no longer under copyright protection.

This document was created from content at the Biodiversity Heritage Library, the world's largest open access digital library for biodiversity literature and archives. Visit BHL at https://www.biodiversitylibrary.org. 